\title{
Fluoxetine and 8-OH-DPAT in the Lateral Septum Enhances and Impairs Retention of an Inhibitory Avoidance Response in Rats
}

\author{
EMINY H. Y. LEE, ${ }^{* 1}$ W. R. LIN, ${ }^{*}$ H. Y. CHEN, ${ }^{* 2}$ W. H. SHIU* AND K. C. LIANG $\dagger$ \\ *Institute of Biomedical Sciences, Academia Sinica and +Department of Psychology, \\ National Taiwan University, Taipei, Taiwan, Republic of China
}

Received 2 July 1991

\begin{abstract}
LEE, E. H. Y., W. R. LIN, H. Y. CHEN, W. H. SHIU AND K. C. LIANG. Fluoxetine and 8-OH-DPAT in the lateral septum enhances and impairs retention of an inhibitory avoidance response in rats. PHYSIOL BEHAV 51(4) 681-688, 1992.-The present study investigated the role of lateral septal serotonin $(5 \mathrm{HT})$ in memory consolidation and the subtype of $5 \mathrm{HT}$ receptors involved in this process. Rats with cannulae implanted bilaterally into the lateral septum were trained in an inhibitory avoidance task. Immediately after training, the septal serotonergic function was manipulated by pharmacological agents selectively blocking $5 \mathrm{HT}$ reuptake (fluoxetine and zimelidine), antagonizing $5 \mathrm{HT}_{2}$ receptors (ketanserin and ritanserin), or activating $5 \mathrm{HT}_{1 \mathrm{~A}}$ receptors, respectively. Results indicated that direct fluoxetine infusions into the lateral septum at a dose of $6 \mu \mathrm{g} / 0.5 \mu \mathrm{l}$ and zimelidine at a dose of $5 \mu \mathrm{g} / 0.5 \mu \mathrm{l}$ both markedly enhanced memory. Intralateral septal injections of ketanserin $(0.3 \mu \mathrm{g} / 0.5 \mu \mathrm{l}$ and $0.5 \mu \mathrm{g} / 0.5 \mu \mathrm{l})$ and ritanserin $(0.3 \mu \mathrm{g} / 0.5 \mu \mathrm{l}$ and $0.6 \mu \mathrm{g} / 0.5 \mu \mathrm{l})$ did not have a significant effect by themselves on memory, and neither did they attenuate the memory-facilitating effect of fluoxetine in the same area. Intralateral septal infusions of 8-hydroxy-2-(di-n-propylamino)tetralin at $5 \mu \mathrm{g} / 0.5 \mu \mathrm{l}$ significantly impaired memory retention. These findings altogether support the notion that the lateral septal nuclei of rats are involved in the memory processes of inhibitory avoidance learning. Furthermore, postsynaptic 5HT receptor activation (not the $5 \mathrm{HT}_{2}$ receptor subtype) probably exerts a facilitatory effect while presynaptic $5 \mathrm{HT}_{1 \mathrm{~A}}$ receptor activation exerts an impairing effect on the memory consolidation process, probably due to autoreceptor inhibition of $5 \mathrm{HT}$ release.
\end{abstract}

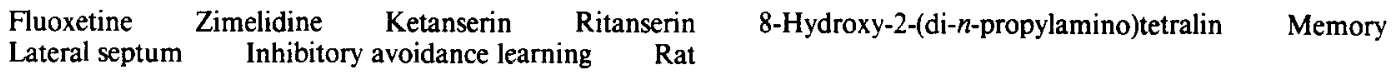

EVIDENCE for the role of serotonin (5HT) in memory processing is far from conclusive. In aplysia, 5HT has been suggested to assume a critical role in presynaptic facilitation underlying sensitization as well as a critical role in classical conditioning $(9,23)$. In vertebrates, while some studies reported that depletion of $5 \mathrm{HT}$ facilitates acquisition or retention performance $(6,37)$, other studies found that manipulations that increase $5 \mathrm{HT}$ accumulation in the synaptic cleft either enhance memory or attenuate amnesia induced by other treatments $(1,24,29,38)$. These conflicting results may be partly because of the use of compounds that lack pharmacological selectivity in affecting the serotonergic system, especially a single subtype of the heterogeneous $5 \mathrm{HT}$ receptors, as well as failure to take anatomical specificities into account.

Fluoxetine is believed to have a high degree of specificity in blocking 5HT uptake without appreciably affecting the dopaminergic and noradrenergic systems $(16,17)$. Flood and Cherkin
(13) have reported that when using the one-trial passive avoidance learning paradigm, systemic injection of fluoxetine enhances memory consolidation and retrieval processes in young adult mice. It also antagonizes amnesia induced by antibiotics or drugs. Similarly, Strek et al. (36) have also found that systemic fluoxetine injection increases the retention latency in a passive avoidance training in rats. However, they also reported that the selective $5 \mathrm{HT}_{2}$ antagonist ketanserin enhances memory retrieval when given after training (36). A similar effect of ketanserin was also found in mice (2).

Despite all the evidence, little is known about the limbic structures in the central nervous system on which fluoxetine might act to affect memory processes. The septum is a structure of the limbic system and is implicated in associative or nonassociative learning and memory $(4,18,28)$, as well as other emotion-related behaviors in vertebrates (22). Anatomically, the septum can be divided into two major parts: the lateral septal

\footnotetext{
${ }^{\prime}$ Requests for reprints should be addressed to Dr. Eminy H. Y. Lee, Institute of Biomedical Sciences, Academia Sinica, Taipei (11529), Taiwan, Republic of China.

${ }^{2}$ Ms. H. Y. Chen is currently a graduate student in the University of California, Los Angeles, CA.
} 
complex including the dorsal, intermedial, and ventral septal nuclei, and the medial septal nucleus along with the diagonal band of Broca. In addition to the anatomical specificity (33), the lateral and medial septal nuclei were demonstrated to be differentiated in neurochemical $(8,21)$, pharmacological $(10)$, and behavioral (25) aspects.

The lateral septum has been reported to be one of the areas containing serotonergic terminals. Recent studies have suggested that there are different subtypes of 5HT receptors (14) that are unevenly distributed within the central nervous system, and the septal nucleus is probably enriched in $5 \mathrm{HT}_{1}$ receptors $(31,32)$. The aims of the present study were to examine (i) whether $5 \mathrm{HT}$ in the lateral septum plays an important role in the memory consolidation process in rats and (ii) which subtype of $5 \mathrm{HT}$ receptors mediates this process. In view of the findings by Strek et al. (36) and by Pazos and Palacios (31), the present study was primarily focused on the involvement of $5 \mathrm{HT}_{1}$ and $5 \mathrm{HT}_{2}$ receptor subtypes.

\section{METHOD}

\section{Animals}

Male Sprague-Dawley rats (200-250 g) bred from the Animal Facility of the Institute of Biomedical Sciences, Academia Sinica were used. They were housed four per cage $(58 \times 34 \times 21 \mathrm{~cm})$ before surgery and housed individually in hanging cages $(30 \times$
$23 \times 20 \mathrm{~cm})$ after surgery, and were maintained on a $12: 12 \mathrm{~h}$ light:dark cycle with food and water continuously available. Experiments were conducted during the light phase of the diurnal rhythm (in a dim room).

\section{Drugs}

Fluoxetine (a generous gift from Eli Lilly), ketanserin, ritanserin, and 8-hydroxy-2-(di- $n$-propylamino)tetralin $\mathrm{HBr}(8-\mathrm{OH}$ DPAT) (from Research Biochemical Inc.) were used. All drugs were dissolved in $0.9 \%$ isotonic saline and were prepared immediately before use. Doses refer to the salt form.

\section{Surgery:}

Animals were subjected to stereotaxic surgery under sodium pentobarbital anesthesia $(40 \mathrm{mg} / \mathrm{kg}$, IP). Stainless steel thin-wall cannulae (23 gauge, $12 \mathrm{~mm}$ long) were implanted bilaterally into the lateral septum. The coordinates for the cannula tip are: $\mathrm{AP}+0.5 \mathrm{~mm}$ from bregma, $\mathrm{ML} \pm 0.6 \mathrm{~mm}$ from midline, $\mathrm{DV}$ $-4.0 \mathrm{~mm}$ below the skull surface according to the atlas of Paxinos and Watson (31). The tooth bar was at $-2.4 \mathrm{~mm}$. Two small stainless steel screws serving as anchors were implanted over the right frontal and left posterior cortices. The cannulae were affixed on the skull with dental cement. A stylet was inserted into each cannula to maintain patency.

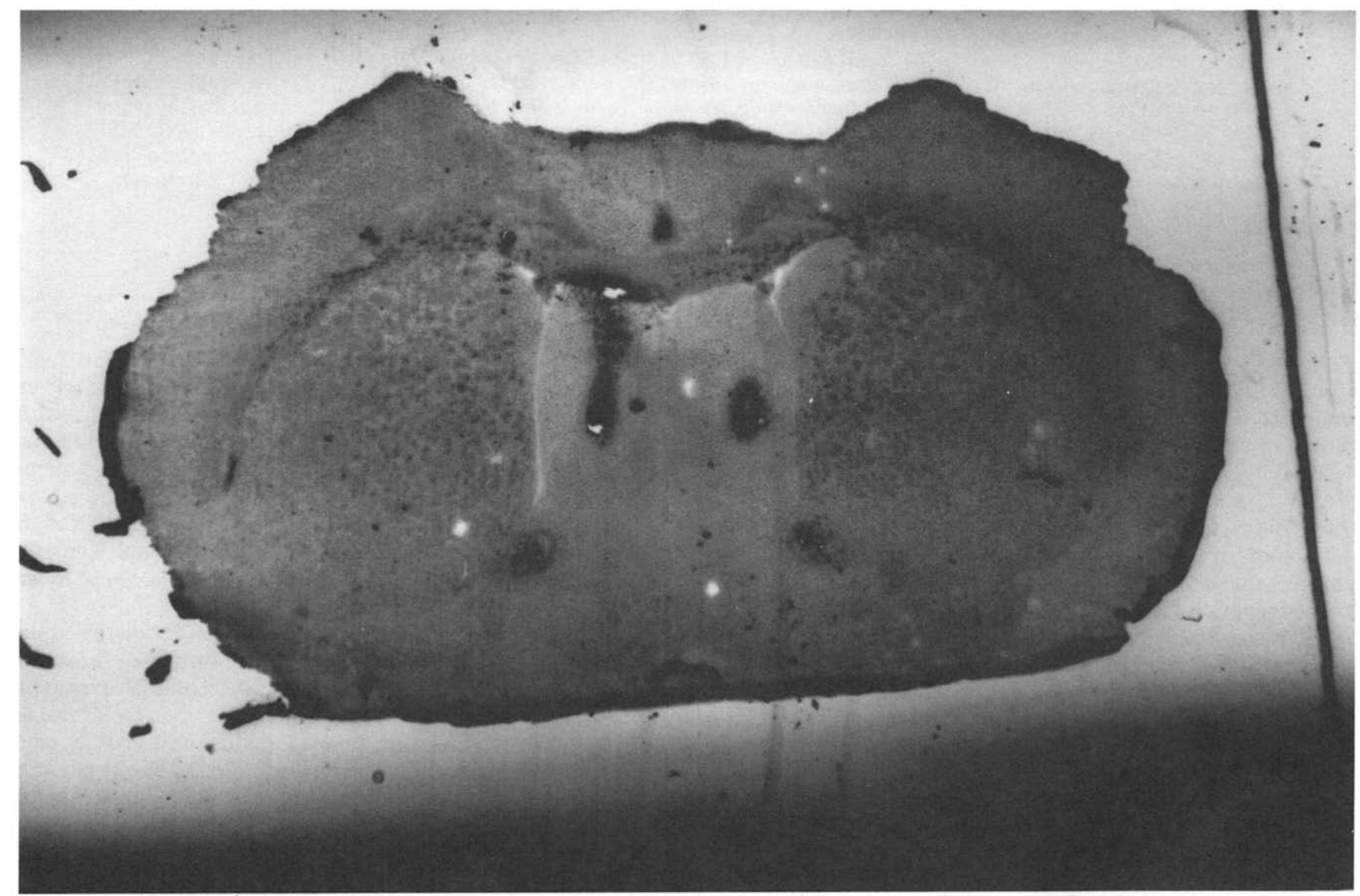

FIG. 1. The typical placement of injection needles, and dye distribution, in the lateral septum in a representative rat. Methylene blue dye $0.5 \mu l(3$ $\mathrm{mg} / \mathrm{ml}$ ) was infused to the lateral septum bilaterally. A $20-\mu \mathrm{m}$-thick section through the lateral septum is shown. 


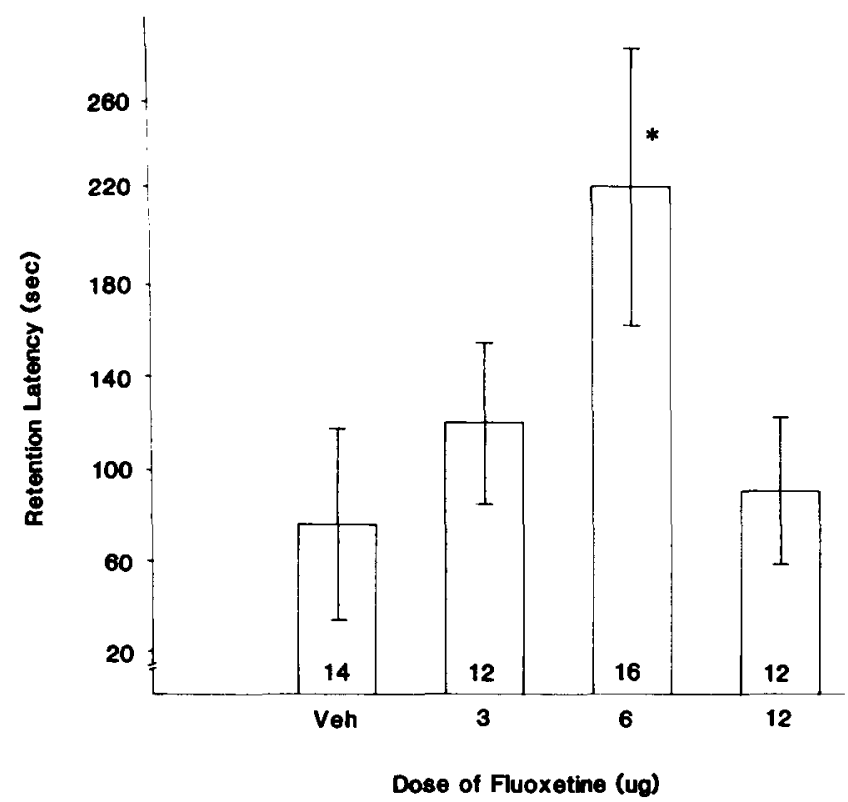

FIG. 2. Dose-response effects of intralateral septal fluoxetine on memory retention of inhibitory avoidance learning in rats. Data are means \pm SEM. The number of animals in each group is indicated in each column. ${ }^{*} p<0.05$ when compared with the control group.

\section{Inhibitory Avoidance Task}

Ten to twelve days after the surgery, rats were trained on a one-trial step through an inhibitory avoidance task. The apparatus consisted of a trough-shape alley $(95 \times 22 \times 34 \mathrm{~cm})$ divided by a sliding door into an illuminated safe compartment $(30 \mathrm{~cm}$ in length) and a dark shock compartment (65 $\mathrm{cm}$ in length). The rat was placed into the safe compartment facing away from the door. As the rat turned around, the door was opened. After the rat entered the dark compartment, the door was closed and a $0.9 \mathrm{~mA} / 1 \mathrm{~s}$ DC current footshock was administered. The rat was removed from the alley about $5 \mathrm{~s}$ after receiving the shock, administered the appropriate post-training treatments, and returned to its home cage. On the retention test given $24 \mathrm{~h}$ later, the rat was again placed into the illuminated compartment and the latency to step into the dark compartment was recorded as a measure of retention performance. Rats which did not enter the dark compartment within $600 \mathrm{~s}$ were removed from the alley and assigned a ceiling score of 600 .

\section{Intralateral Septum Drug Administration}

Animals received bilateral injections of vehicle (Veh) or drug into the lateral septum immediately after the inhibitory avoidance training. The animal was awake and gently held by the experimenter when receiving injections. The injection was administered through a 30 -gauge injection needle connected to a $2 \mu \mathrm{l}$ Hamilton microsyringe by $0.5 \mathrm{~m}$ polyethylene tubing (PE20). The injection needle was bent at a length such that, when inserted into the cannula, the needle tip would protrude $1.5 \mathrm{~mm}$ beyond the tip of the cannula. Drug solutions were introduced into the PE tubing and the microsyringe, and were delivered into the lateral septum manually at a rate of $0.5 \mu \mathrm{l} / \mathrm{min}$. A total volume of $0.5 \mu \mathrm{l}$ was injected into each side for all drugs in all experiments.

\section{Histology}

At the completion of the memory test, animals were sacrificed by decapitation and the brains were removed. For histological examination of cannula and needle placement in the lateral septum, the brains were frozen-sectioned in a cryostat. Twentymicron thick sections taken at $40 \mu \mathrm{m}$ intervals through the lateral septum were mounted on slides and stained with thionine blue, and the cannula track was examined for each rat. Animals were accepted for data analysis only if both needle placements were located within the lateral septum. Figure 1 illustrates the placement of the needle position in the lateral septum under microscopic examination. There were several animals whose cannula tip was not located at the right position and their data were not included in analysis regardless of their memory performance.

\section{Statistics}

Since the distribution of retention scores was truncated at 600 , nonparametric Mann-Whitney two-tailed $U$-tests (34) were used to analyze the data for the inhibitory avoidance task. The $U$ value was transformed to a $Z$ value if the number of subjects in each group was greater than 8 .

\section{EXPERIMENT 1}

If $5 \mathrm{HT}$ in the lateral septum plays a modulatory role in memory retention, it is predicted that the specific 5HT uptake blocker fluoxetine, when injected into the lateral septum, should affect memory processing. This experiment was designed to test this hypothesis. Fifty-eight animals were randomly assigned to four groups for a dose-response study of fluoxetine's effect on memory. Group I $(n=14)$ received saline infusions, group II

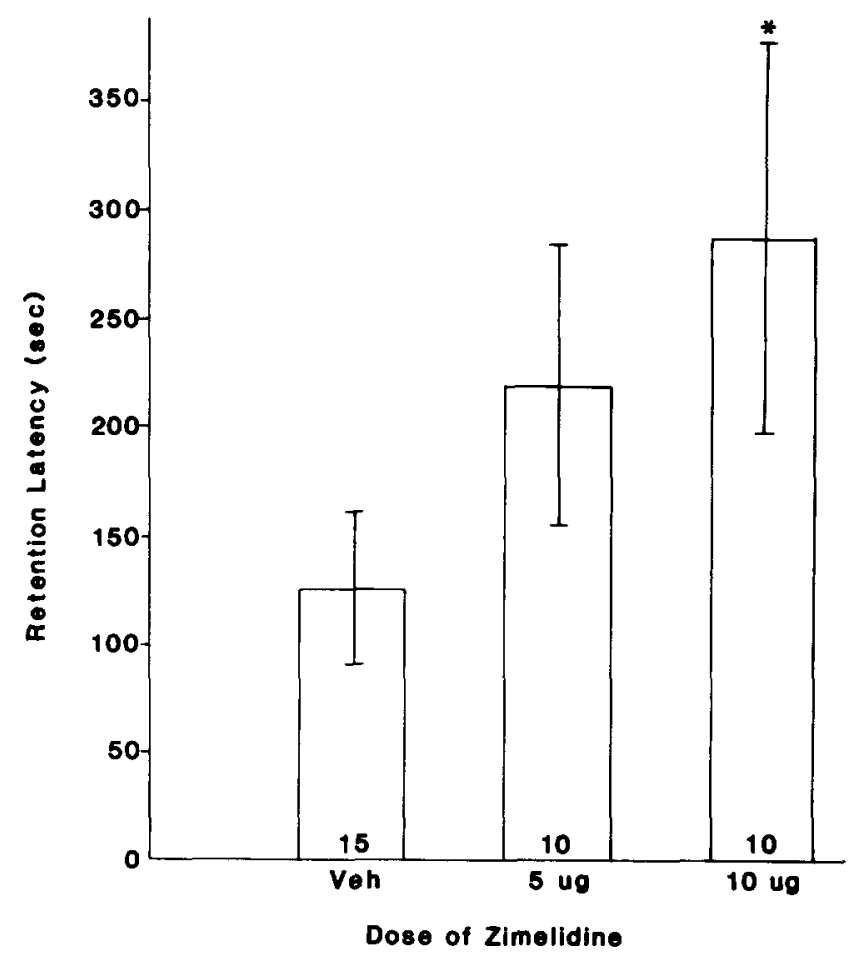

FIG. 3. Dose-response effects of intralateral septal zimelidine on memory retention of inhibitory avoidance learning in rats. Data are expressed as in Fig. 2. 


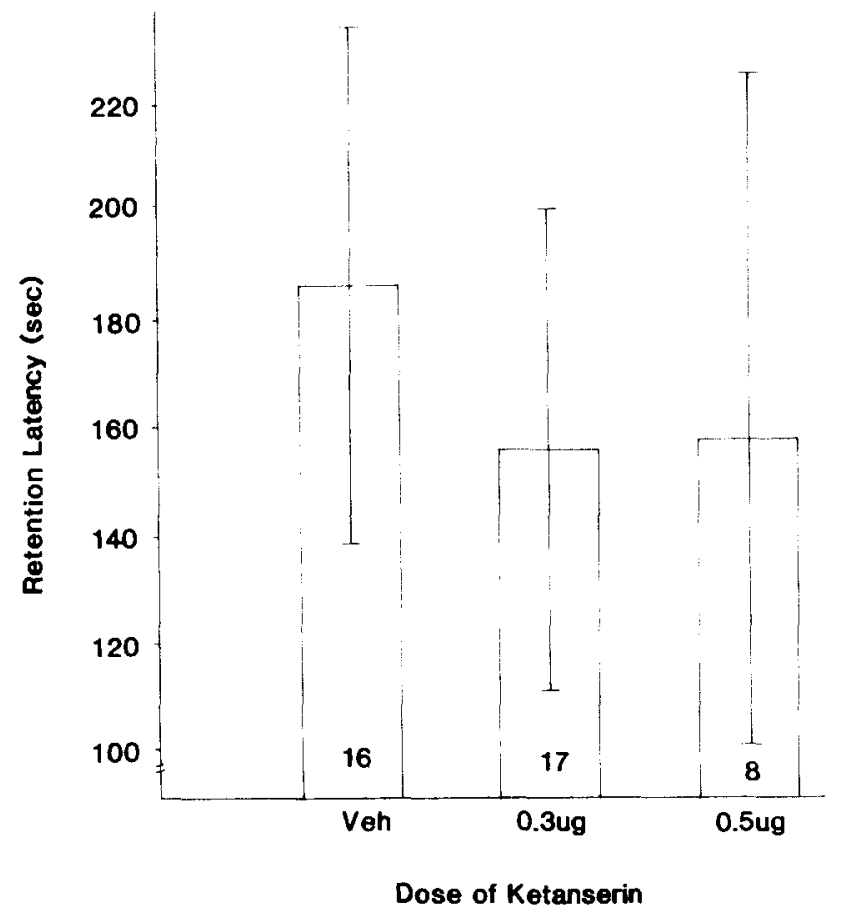

FIG, 4. Dose-response effects of intralateral septal ketanserin on memory retention of inhibitory avoidance learning in rats. Data are expressed as in Fig. 2.

( $n=13$ ) received fluoxetine infusions at $3 \mu \mathrm{g} / 0.5 \mu \mathrm{l}$ per side, group III $(n=18)$ received fluoxetine infusions at $6 \mu \mathrm{g} / 0.5 \mu \mathrm{l}$ per side, and group IV $(n=13)$ received fluoxetine infusions at $12 \mu \mathrm{g} / 0.5 \mu \mathrm{l}$ per side. The injection volume was $0.5 \mu \mathrm{l}$ each side. The dose range adopted was calculated from findings of a previous study (13) considering both the injection route and species differences.

\section{EXPERIMENT 2}

Since the results from Experiment 1 indicated that fluoxetine enhanced memory retention at a $6-\mu \mathrm{g}$ dose only, another specific $5 \mathrm{HT}$ uptake blocker zimelidine was used in this study to further confirm that 5HT in the lateral septum possibly plays a facilitatory role in the memory process. Forty rats were divided into three groups. Group I $(n=16)$ received saline infusions, group II $(n=12)$ received zimelidine infusions at $5 \mu \mathrm{g} / 0.5 \mu \mathrm{l}$ each side, and group III $(n=12)$ received zimelidine infusions at 10 $\mu \mathrm{g} / 0.5 \mu \mathrm{l}$ each side.

\section{EXPERIMENT 3}

In this study, the dose-response effects of the selective $5 \mathrm{HT}_{2}$ receptor blocker ketanserin on memory performance were examined. Forty-four rats were distributed to three groups. Group I $(n=16)$ received saline, group II $(n=15)$ received $0.3 \mu \mathrm{g} / 0.5$ $\mu \mathrm{l}$ ketanserin, and group III $(n=13)$ received $0.5 \mu \mathrm{g} / 0.5 \mu \mathrm{l} \mathrm{ke}-$ tanserin; for each group infusions were delivered into each lateral septum.

\section{EXPERIMENT 4}

This experiment was designed to study whether ketanserin antagonizes the memory-enhancing effect of fluoxetine in the lateral septum. Thirty-eight rats were randomly assigned to three groups. Group I $(n=14)$ received saline and saline infusions. group II $(n=12)$ received saline and fluoxetine infusions $(6 \mu \mathrm{g} /$ $0.5 \mu \mathrm{l})$, and group III $(n=12)$ received ketanserin $(0.3 \mu \mathrm{g} / 0.5$ $\mu \mathrm{l})$ followed by fluoxetine $(6 \mu \mathrm{g} / 0.5 \mu \mathrm{l})$ infusions. The first infusion was given $30 \mathrm{~min}$ before training and the second infusion given immediately after training.

\section{EXPERIMENT 5}

In order to further test the specificity of $5 \mathrm{HT}_{2}$ receptor involvement in the memory consolidation process, the effects of another $5 \mathrm{HT}_{2}$ receptor blocker ritanserin on memory retention were examined. Thirty-six rats were divided into three equal number groups. Group I received bilateral saline infusions, group II received ritanserin infusions at a dose of $0.3 \mu \mathrm{g} / 0.5 \mu \mathrm{l}$ each side, and group III received ritanserin infusions at a dose of 0.6 $\mu \mathrm{g} / 0.5 \mu \mathrm{l}$ each side.

\section{EXPERIMENT 6}

This experiment was designed to study the interactive effects of ritanserin and fluoxetine in the lateral septum on memory retention in rats. Forty rats were randomly assigned to three groups. Group I ( $n=13)$ received saline and saline infusions, group II $(n=13)$ received ritanserin $(0.3 \mu \mathrm{g} / 0.5 \mu \mathrm{l})$ and saline infusions, and group III $(n=14)$ received ritanserin $(0.3 \mu \mathrm{g} / 0.5$ $\mu \mathrm{l})$ and fluoxetine $(6 \mu \mathrm{g} / 0.5 \mu \mathrm{l})$ infusions. Similarly, the first infusion was given $30 \mathrm{~min}$ prior to, and the second infusion given immediately after. the training procedure.

\section{EXPERIMENT 7}

This study was designed to examine whether $5 \mathrm{HT}$, receptors in the lateral septum are involved in the memory process in rats. Specific $5 \mathrm{HT}_{1 \mathrm{~A}}$ receptor agonist 8 -OH-DPAT $(20,28)$ was used. Forty animals were randomly divided into three equal groups. Group I $(n=12)$ received bilateral saline infusions, group II ( $n$ $=14$ ) received bilateral $8-O H-D P A T$ infusions at $1 \mu \mathrm{g} / 0.5 \mu \mathrm{l}$, and group III $(n=14)$ received bilateral 8-OH-DPAT infusions at $5 \mu \mathrm{g} / 0.5 \mu \mathrm{l}$.

\section{RESULTS}

\section{EXPERIMENT 1}

The dose-response effects of fluoxetine on memory retention are shown in Fig. 2. Intralateral septal infusions of fluoxetine, at a dose of $6 \mu \mathrm{g} / 0.5 \mu \mathrm{l}$, significantly enhanced memory retention $(Z=2.18, p<0.05)$. Whereas fluoxetine at a higher and a lower dose had no significant effect $(Z=0.73$ and $Z=0.51$, respectively; both $p>0.05$ ).

\section{EXPERIMENT 2}

The dose-response effects of zimelidine on memory performance are shown in Fig. 3. As revealed from this figure, zimelidine dose-dependently improved retention performance with the $10 \mu \mathrm{g} / 0.5 \mu \mathrm{l}$ dose reaching a significant level $(Z=1.99, p<$ $0.05)$.

\section{EXPERIMENT 3}

The dose-response effects of the selective $5 \mathrm{HT}_{2}$ receptor blocker ketanserin on memory retention are illustrated in Fig. 4. As shown in this figure, ketanserin injected into the lateral 
septum did not have a significant effect on memory retention at either dose examined $(Z=0.25$ and $Z=0.14$ for $0.3 \mu \mathrm{g}$ and $0.5 \mu \mathrm{g}$ ketanserin, respectively; both $p>0.05$ ).

\section{EXPERIMENT 4}

The interactive effects of ketanserin and fluoxetine in the lateral septum on memory consolidation in rats are shown in Fig. 5. In replication of the results of Experiment $1,6 \mu \mathrm{g}$ of fluoxetine consistently and markedly improved retention performance in rats $(Z=2.04, p<0.05)$. Ketanserin at $0.3 \mu \mathrm{g}$ did not affect memory retention by itself (from Experiment 3 ), and it did not antagonize the memory-facilitating effect of fluoxetine either. The ketanserin/fluoxetine group had significantly better retention performance than the controls $(Z=1.96, p<0.05)$.

\section{EXPERIMENT 5}

The dose-response effects of ritanserin on memory performance are shown in Fig. 6. Similar to the effects of ketanserin, ritanserin did not markedly affect memory retention at either dose examined $(Z=0.41$ and $Z=0.23$ for $0.3 \mu \mathrm{g}$ and $0.6 \mu \mathrm{g}$ doses, respectively; both $p>0.05$ ).

\section{EXPERIMENT 6}

The interactive effects of ritanserin and fluoxetine in the lateral septum on retention are summarized in Fig. 7. Ritanserin at $0.3 \mu \mathrm{g}$ did not affect memory retention by itself $(Z=0.31, p$ $>0.05)$, neither did it antagonize the memory-facilitating effect of fluoxetine $(6 \mu \mathrm{g})$ in the lateral septum $(Z=1.98, p<0.05$, when comparing the ritanserin/fluoxetine group with the control group).

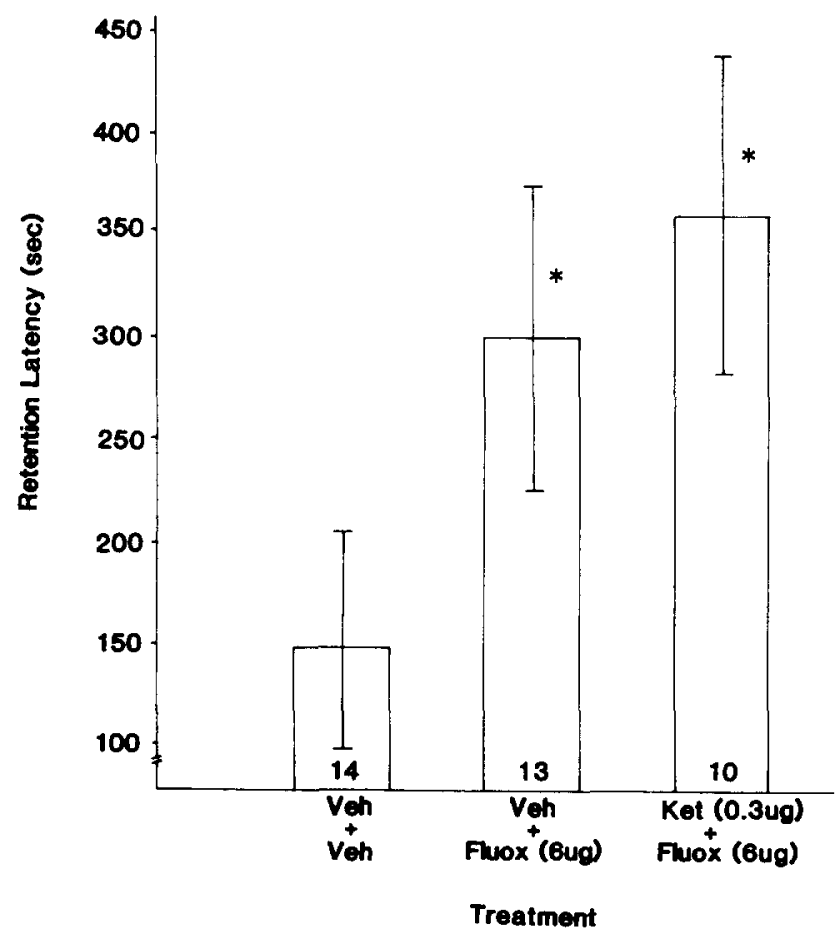

FIG. 5. Interactive effects of fluoxetine and ketanserin in the lateral septum on memory retention of inhibitory avoidance learning in rats. Data are expressed as in Fig. 2.

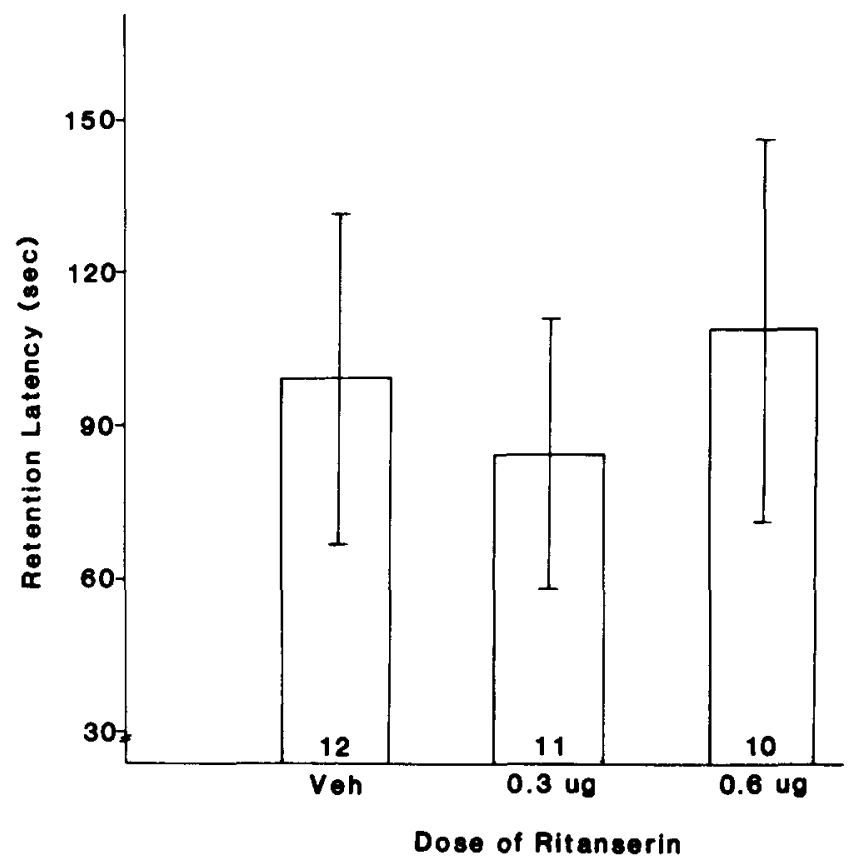

FIG. 6. Dose-response effects of intralateral septal ritanserin on memory retention of inhibitory avoidance learning in rats. Data are expressed as in Fig. 2.

\section{EXPERIMENT 7}

The dose-response effects of 8-OH-DPAT on memory retention are shown in Fig. 8. 8-OH-DPAT at $1 \mu \mathrm{g}$ did not have a significant influence upon memory by itself $(Z=1.77, p>$ $0.05)$, while 8-OH-DPAT at a higher dose $(5 \mu \mathrm{g})$ markedly impaired memory retention $(Z=1.97, p<0.05)$.

\section{DISCUSSION}

The present results demonstrate that, at appropriate doses, the specific 5HT uptake blockers fluoxetine and zimelidine both significantly improved retention performance in rats. Injections of specific $5 \mathrm{HT}_{2}$ receptor blockers ketanserin and ritanserin did not prevent this memory-enhancing effect of fluoxetine in the lateral septum. On the other hand, injection of the $5 \mathrm{HT}_{1 \mathrm{~A}}$ receptor agonist 8-OH-DPAT markedly impaired memory retention. These results together suggest that synaptic 5HT in the lateral septum probably plays a facilitatory role in memory processing in rats and this effect is probably not mediated through the $5 \mathrm{HT}_{2}$ receptor subtype. Furthermore, activation of septal $5 \mathrm{HT}_{1 \mathrm{~A}}$ receptors, presumably at presynaptic sites, impaired memory processing, probably due to autoreceptor inhibition of $5 \mathrm{HT}$ release.

These results are consistent with the findings of Flood and Cherkin (13) that systemic injection of fluoxetine enhances memory processing in mice, and the finding that systemic $p$ chlorophenylalanine, a drug that depletes $5 \mathrm{HT}$, retards passive avoidance learning in rats (35). In another study, Wenk et al. (39) have reported that the specific 5HT neurotoxin 5,7-dihydroxytryptamine (5,7-DHT) impaired acquisition in rats. While zimelidine enhanced memory in a dose-response fashion, fluoxetine did not have a memory-facilitating effect at the higher dose examined $(12 \mu \mathrm{g} / 0.5 \mu \mathrm{l})$. This is probably due to the relatively high dose of the drug used that partially overrides the 


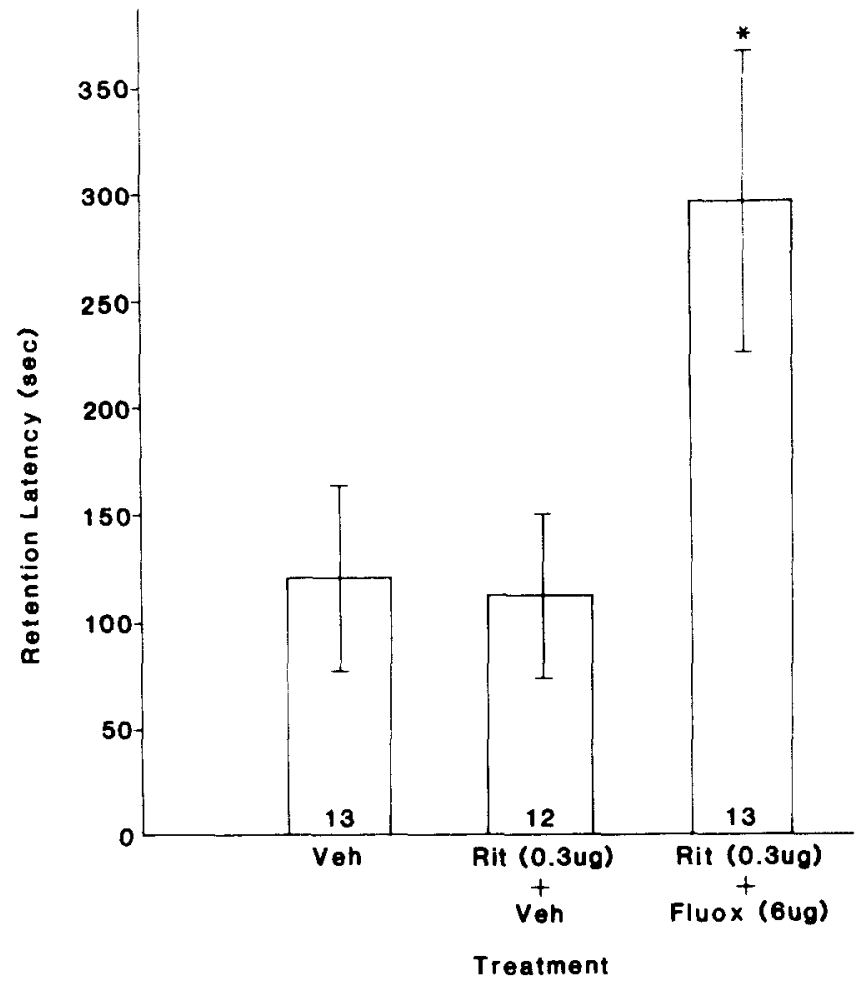

FIG. 7. Interactive effects of fluoxetine and ritanserin in the lateral septum on memory retention of an inhibitory avoidance task in rats. Data are expressed as in Fig. 2.

pharmacological specificity. This suggestion is supported by the findings of Caccia et al. (7) that fluoxetine follows apparent firstorder kinetics when injected in the $10 \mathrm{mg} / \mathrm{kg}$ dose range. In addition, the memory score in control animals was relatively lower in the fluoxetine dose-response study (Fig. 2) when compared with others. This is probably due to the relatively old rats used in this experiment ( 3 weeks older on the average). On the other hand, the medial septal nucleus has more frequently been studied and implicated in memory processes $(3,5)$, while the role of the lateral septal nucleus has rarely been investigated. We have presently demonstrated that the lateral septum is also an important structure in modulating the learning and memory processes in mammals.

While the current results are consistent with many studies emphasizing the facilitatory role of 5HT in learning and memory, there are also studies showing opposite results. For example, Fibiger et al. (11) have reported that electrical stimulation of the dorsal raphe nucleus disrupts memory in rats in a step-down passive avoidance paradigm. Using an active avoidance paradigm, Ogren (29) has reported that acute release of 5 HT by $p$ chloroamphetamine also impairs the acquisition and retention of one-way active avoidance learning in rats. Fletcher (12) has found that tryptamine produces an acquisition deficit in an active avoidance task in rats, which is possibly caused by stimulation of central 5HT receptors. Other than differences in experimental designs and behavioral paradigms, most of these studies have used the systemic injection route which apparently lacks anatomical specificity. Considering the growing evidence showing differential roles of various receptor subtypes even within the same neurotransmitter system, these approaches lack neurochemical specificity. The refined pharmacological, anatomical, as well as neurochemical specificities of our current treatments, therefore, provide better evidence for a facilitatory role of $5 \mathrm{HT}$ in the lateral septum in memory formation, and may account for the discrepancies among these findings.

The present results also indicate that the $5 \mathrm{HT}$ receptors in the lateral septum involved in memory processing at least include presynaptic $5 \mathrm{HT}_{1 \mathrm{~A}}$ receptors. The $5 \mathrm{HT}_{2}$ receptor subtype is probably not involved. since the selective $5 \mathrm{HT}_{2}$ receptor blockers ketanserin and ritanserin did not have any significant effect upon memory by themselves, and they did not antagonize the memory-enhancing effect of fluoxetine in this area either. In a study reported by Strek et al. (36) fluoxetine increased retention latency, as we found in the present study. These investigators also found that systemic injection of ketanserin, which presumably has a neurochemical action opposite to that of fluoxetine, also increases retention performance in a passive avoidance task in rats. While these seemingly contradictory results remain to be reconciled, they nonetheless suggest that the memory-enhancing effect of fluoxetine and zimelidine and the facilitatory role of $5 \mathrm{HT}$ on memory is probably not mediated through the $5 \mathrm{HT}_{2}$ receptor subtype. On the contrary, activation of $5 \mathrm{HT}_{2}$ receptors may play an inhibitory role in memory consolidation, as suggested by Strek et al. (36). In view of the fact that the distribution of $5 \mathrm{HT}$ receptor subtypes and the density of each subtype vary substantially within the brain (31), and that even the same 5HT receptor subtype in different brain regions may be functionally differentiated (14), discrepancies between the effects of systemic and local ketanserin injections are not surprising.

The septal nuclei are rich in $5 \mathrm{HT}$, receptors, probably the lA subtype, as suggested by Pazos and Palacios (31). The present results indicated that injections of a $5 \mathrm{HT}_{1 \mathrm{~A}}$ agonist $8-\mathrm{OH}$-DPAT into the lateral septum produced a significant memory-impairing effect. Such findings seem to be incongruent with the facilitatory effect of fluoxetine if 8 -OH-DPAT is assumed to work postsyn-

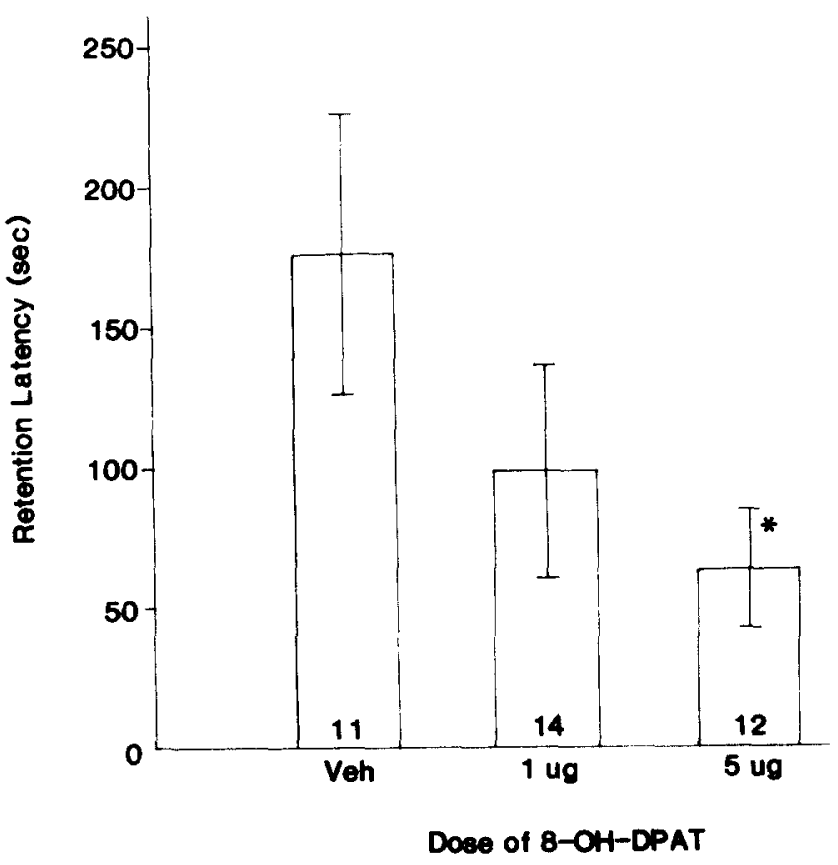

FIG. 8. Dose-response effects of intralateral septal 8-OH-DPAT on memory retention of an inhibitory avoidance task in rats. Data are expressed as in Fig. 2. 
aptically. However, recent findings have shown the existence of $5 \mathrm{HT}_{1 \mathrm{~A}}$ receptors on serotonergic terminals in many forebrain regions (20) including those implicated in memory processing, such as the hippocampus (26). Therefore, the injected 8-OHDPAT may work through presynaptic $5 \mathrm{HT}_{1 \mathrm{~A}}$ receptors to inhibit endogenous $5 \mathrm{HT}$ release activated by the training experience and hence induces an effect opposite to that of fluoxetine. There are other subtypes of $5 \mathrm{HT}_{1}$ receptors $(1 \mathrm{~B}, 1 \mathrm{C}$, and possibly $1 \mathrm{D}$ ) and $5 \mathrm{HT}_{3}$ receptors whose role in memory processes remains unclear and may mediate the postsynaptic effect of endogenously released 5HT. Further studies to examine the effects of selective $5 \mathrm{HT}_{1}$ (including various forms of $5 \mathrm{HT}_{1}$ receptors) and $5 \mathrm{HT}_{3}$ antagonists, as well as the anatomical locus of these receptors on memory, are warranted. In addition, examination of the roles of different $5 \mathrm{HT}$ receptor subtypes in other brain regions, such as the hippocampus and the amygdala, which are also implicated in modulating learning and memory processes will also be helpful.
In summary, using the one-way inhibitory avoidance paradigm and the local infusion technique, given the pharmacological, anatomical, and neurochemical specificities of the adopted treatments, we found in the present study that the serotonergic neurons in the lateral septum play a facilitatory role in memory retention in rats. Furthermore, this memory-enhancing effect of presynaptically released $5 \mathrm{HT}$ in the lateral septum is probably not mediated through the $5 \mathrm{HT}_{2}$ receptor subtype; injection of selective $5 \mathrm{HT}_{1 \mathrm{~A}}$ agonist in the same area produced a memoryimpairing effect probably due to its inhibition of 5HT release through presynaptic autoreceptors.

\section{ACKNOWLEDGEMENTS}

This work was supported by a Grant from the National Science Council of Taiwan (NSC78-0412-B001-14) and the research fund from the Institute of Biomedical Sciences, Academia Sinica, Taiwan. Dr. K. C. Liang was supported by National Taiwan University. The gift of fluoxetine by the Lilly $\mathrm{Co}$. is gratefully acknowledged.

\section{REFERENCES}

1. Altman, H. J.; Nordy, D. A.; Ogren, S. O. Role of serotonin in memory: Facilitation by alaproclate and zimelidine. Psychopharmacology (Berlin) 84:496-502; 1984.

2. Altman, H. J.; Normile, H. J. Enhancement of the memory of a previously learned aversive habit following pre-test administration of a variety of serotonergic antagonists in mice. Psychopharmacology (Berlin) 90:24-27; 1986 .

3. Bostock, E.; Gallagher, M.; King, R. A. Effects of opioids microinjections into the medial septal area on spatial memory in rats. Behav. Neurosci. 102:643-652; 1988

4. Breshnahan, J. C.; Meyer, P. M.; Baldwin, R. B. Avoidance behavior in rats with lesions in the septum, fornix longus and amygdala. Physiol. Psychol. 4:333-340; 1976.

5. Brioni, J. D.; Decker, M. W.; Gamboa, L. P.; Izquierdo, I.; McGaugh, J. L. Muscimol injections in the medial septum impair spatial learning. Brain Res. 522:227-234; 1990.

6. Brody, J. F. Behavioral effect of serotonin depletion of p-chlorophenylalanine in rats. Psychopharmacologia $13: 14-33 ; 1970$.

7. Caccia, S.; Cappi, M.; Fracasso, C.; Garattini, S. Influence of dose and route of administration on the kinetics of fluoxetine and its metabolite norfluoxetine in the rat. Psychopharmacology (Berlin) 100:509-514; 1990.

8. Chafetz, M. D.; Thompson, R. G.; Evans, S. H.; Gage, F. H. Biochemical specificity of septal hyperreactivity: A behavioral discrimination. Behav. Brain Res. 2:409-420; 1981.

9. Dale, N.; Schacher, S.; Kandel, E. R. Long-term facilitation in aplysia involves increase in transmitter release. Science 239:282-285; 1988.

10. Durkin, T.; Galey, D.; Micheau, J.; Beslon, H.; Jaffard, R. The effects of acute intraseptal injection of haloperidol in vivo on hippocampal cholinergic function in the mouse. Brain Res. 376:420-424; 1986.

11. Fibiger, H. C.; Lepiane, F. G.; Phillips, A. G. Disruption of memory produced by stimulation of the dorsal raphe nucleus: Mediation by serotonin. Brain Res. 155:380-386; 1978.

12. Fletcher, P. J. Tryptamine impairs the acquisition of a one-way active avoidance task. Pharmacol. Biochem. Behav. 32:317-321; 1989.

13. Flood, J. F; Cherkin, A. Fluoxetine enhances memory processing in mice. Psychopharmacology (Berlin) 93:36-43; 1987.

14. Frazer, A.; Magyani, S.; Wolfe, B. B. Subtypes of receptors for serotonin. Annu. Rev. Pharmacol. Toxicol. 30:307-348; 1990.

15. Fuller, R. W.; Perry, K. W.; Molloy, B. B. Effect of an uptake inhibitor on serotonin metabolism in rat brain: Studies with 3-(p-trifluoromethylphenoxy)- $N$-methyl-3-phenylpropylamine. Life Sci. 15:1161$1171 ; 1974$.

16. Fuller, R. W.; Perry, K. W.; Molloy, B. B. Effect of 3-(p-trifluoromethylphenoxy)- $N, N$-methyl-3-phenylpropylamine on the depletion of brain serotonin by 4-chloroamphetamine. J. Pharmacol. Exper. Ther. 193:793-803; 1975.
17. Fuller, R. W. Functional consequences of inhibiting serotonin uptake with fluoxetine in rats. In: Ho, B. T., ed. Serotonin in biological psychiatry. New York: Raven Press; 1982:219-228.

18. Gallagher, M.; Meagher, M. W.; Bostock, E. Effects of opiate manipulations on latent inhibition in rabbits: Sensitivity of the medial septal region to intra-cranial treatments. Behav. Neurosci. 101:315324: 1987

19. Hjorth, S.; Carlsson, A.; Clark, D.; Svensson, K.; Wikström, H.; Sanchez, D.; Lindberg, P.; Hacksell, U.; Arvidsson, L.-E.; Johansson, A.; Nilsson, J. L. The search for selective dopaminergic autoreceptor agonists. J. Neural Transm. 18:131-137; 1982.

20. Hjorth, S.; Sharp, T. Effect of the 5-HT IA receptor agonist 8-OHDPAT on the release of 5-HT in dorsal and median raphe-innervated rat brain regions as measured by in vivo microdialysis. Life Sci. 48 1779-1786; 1991 .

21. Joels, M.; Urban, J. A. Monoamine-induced responses in lateral septal neurons: Influence of iontophoretically applied vasopressin. Brain Res. 344:120-126; 1985.

22. Johnson, D. A.; Chang, C.; Polenchar, B. E.; Patterson, M. M. The effect of septal lesion on the open-field social behavior of SpragueDawley albino rats. Bull. Psychoneuroendocrin. Soc. 23:339-340; 1985.

23. Kandel, E. R.; Goelet, P.; Gastellucci, V. F. Initial steps toward a molecular biology of long-term memory. In: Chien, S., ed. Molecular biology in physiology. New York: Raven Press; 1989:1 19-147.

24. Kubo, T.; Shibanoki, S.; Matsumoto, A.; Tsuda, K.; Ishikawa, K. Portacaval anastomosis attenuates the impairing effect of cyprohetadine on avoidance learning in rats-an involvement of serotonergic system. Behav. Brain Res. 30:279-287; 1988.

25. Lee, E. H. Y.; Lin, Y. P.; Yin, T. H. Effects of lateral and medial septal lesions on various activity and reactivity measures in rats. Physiol. Behav, 42:97-102; 1988.

26. Maura, G.; Roccatagliata, E.; Raiteri, M. Serotonin autoreceptor in rat hippocampus: Pharmacological characterization as a subtype of the 5-HT1 receptor. Naunyn-Schmiedeberg's Arch Pharmacol. 334: $323-326 ; 1986$

27. Middlemiss, D. N.; Fozard, J. R. 8-hydroxy-2-(di- $n$-propylamino)tetralin discriminates between subtypes of the $5-\mathrm{HT}_{1}$ recognition site. Eur. J. Pharmacol. 90:151-153; 1983.

28. Nielson, D. A.; Mclver, A. H.; Boswell, R. S. Effect of septal lesions on learning, emotionality, activity and exploratory behavior in rats. Exp. Neurol. 11:147-157; 1965

29. Ogren, S. O. Forebrain serotonin and avoidance learning: Behavioural and biochemical studies on the acute effect of $p$ chloroamphetamine on one-way active avoidance learning in the male rat. Pharmacol. Biochem. Behav. 16:881-895; 1982. 
30. Paxinos, G: Watson, $C$. The rat brain in stereotaxic coordinates. 2nd ed. Orlando: Academic Press: 1986.

31. Pazos, A.: Palacios, J. M. Quantitative autoradiographic mapping of serotonin receptors in the rat brain. I. Serotonin-1 receptors. Brain Res. 346:205-230; 1985

32. Pazos, A.: Cortes. R.: Palacios. J. M. Quantitative autoradiographic mapping of serotonin receptors in the rat brain. II. Serotonin-2 receptors. Brain Res. 346:231-249; 1985.

33. Raisman. G. The connections of the septum. Brain Res. 89:317349: 1966

34. Siegel, M. Nonparametric statistics for the behavioral sciences. New York: McGraw-Hill; 1956.

35. Stevens, D. A.; Fechter, L. D. The effects of $p$-chlorophenylalanine, a depletor of brain serotonin, on behavior: II. Retardation of passive avoidance learning. Life Sci. 8:379-385: 1969.
36. Strek, K. F. Spencer K, R. DeNoble, V J Manipulation of serotonin protects against an hypoxia-induced deficit of a passive avoidance response in rats. Pharmacol. Biochem. Behav. 33:241.. 244: 1989.

37. Tennen, S. S. The effects of p-chlorophenylalanine, a serotonin depletor, on avoidance acquisition, pain sensitivity and related behavior in rats. Psychopharmacologia 10:204-219: 1967.

38. Weingertner, H.: Buchsbaum, M. S.; Lennoila, M. Zimelidine effects on memory impairments produced by ethanol. Life Sci. 33:21592163: 1983 .

39. Wenk, G.: Hughey, D.: Boundy, V.: Kim, A.: Walker, L.: Olton, D. Neurotransmitter and memory: Role of cholinergic, serotonergic and noradrenergic systems. Behav. Neurosci. 101:325-332: 1987. 